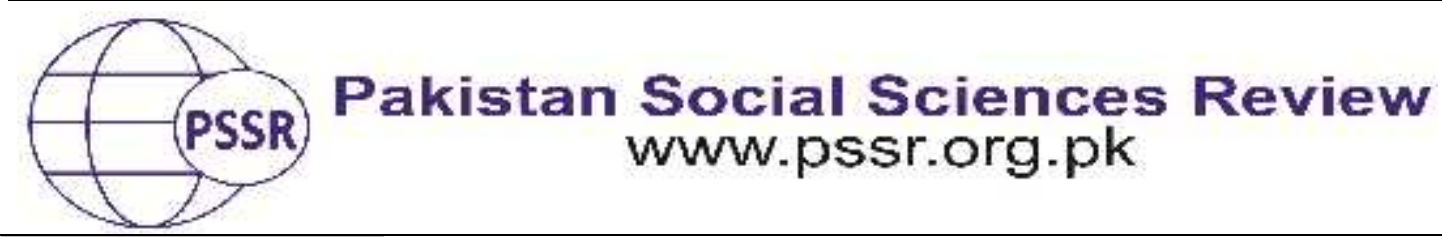

RESEARCH PAPER

\title{
Impact of Budget Deficit on Economic Growth and Investment in Pakistan
}

\author{
Dr. Rummana Zaheer ${ }^{1}$ Sumbul Jahan* 2
}

1. Associate Professor, Department of Economics, University of Karachi, Karachi, Sindh, Pakistan

2. Ph. D Scholar, Department of Economics, University of Karachi, Karachi, Sindh, Pakistan

\begin{tabular}{|c|c|}
\hline PAPER INFO & \\
\hline $\begin{array}{l}\text { Received: } \\
\text { January 06, } 2021 \\
\text { Accepted: } \\
\text { March 01, } 2021 \\
\text { Online: } \\
\text { March 15, } 2021\end{array}$ & $\begin{array}{l}\text { This study elaborates the impacts of budget deficit.Empirical } \\
\text { research indicates that the shortfall has unfavourable } \\
\text { consequences on the threshold, with a fiscal deficit of } 5.67 \% \text { of } \\
\text { GDP. Fiscal policy will, therefore, stimulate inflation if the fiscal } \\
\text { gap remains below the level. A balanced budget of a nation is }\end{array}$ \\
\hline $\begin{array}{l}\text { Keywords: } \\
\text { Degree of the } \\
\text { Threshold, } \\
\text { Economic } \\
\text { Development, } \\
\text { Fiscal Surplus, } \\
\text { STAR }\end{array}$ & $\begin{array}{l}\text { essential to achieve sustainable economic development. } \\
\text { Pakistan's budget deficit has detrimental economic } \\
\text { development impact, study finds. Some measures to discourage } \\
\text { such budget debt amounts from exceeding the target amount of } \\
\text { increase are planned. The findings have shown that GDP }\end{array}$ \\
\hline $\begin{array}{l}\text { *Corresponding } \\
\text { Author } \\
\text { sumbul.jahan@gmai } \\
\text { l.com }\end{array}$ & $\begin{array}{l}\text { contributes to savings and deficit. The budget deficit, however, } \\
\text { would not raise GDP, according to the report. The report often } \\
\text { promotes Keynesian budget shortfall beliefs, it says. }\end{array}$ \\
\hline
\end{tabular}

\section{Introduction}

Discussing the position of the financial inadequacy in economic growth here in literature, is a considerable part. Studies on the basis of the neoclassical school of thinking claims that by placing the fiscal gap in jeopardy of economic development, on the basis of rising government spending, which forces out private expenditure, pressure on the interest rate. Other reports by utilizing the key-nesian approach indicate that the fiscal deficit will fuel domestic growth, adding to private investors' economic success and generating increased investment, known as the "crowd-in" effect (Bernheim, 1989). Realistic assumptions indicate expansionary debt-financed monetary policy does not help to raise demand, since agents foresee future tax hikes and thus adjust their spending (under the Hypothesis of Ricardian Equality). An evolving fiscal policy helps minimize public savings, which encourages the required private savings to grow slowly. As a consequence, the desired national savings would not adjust at all. Consequently, in order to preserve a compromise between 
national saving and spending demand, the actual interest rate would not need to increase, keeping total production unchanged (Saleh \&Harvie, 2005).

The empirical evidence is inconclusive as to the effect of the productivity fiscal shortfall. One part of the literature from fiscal deficit to economic growth has a good connection, although other analysis finds that there is a detrimental alliance. These mixed findings demonstrate the likelihood that the fiscal deficit and economic growth will be non-linear. This, in particular, could result in a ceiling for fiscal deficits showing to what extent tax growth could be an instrument for development policy.

The role of this threshold has been examined in recent analytical reports in the link between fiscal deficit and economic development. The limits for fiscal deficits, which are around 1.5\% of GDP, indicate that higher fiscal deficits hinder economic development, have shown Adam and Bevan (2005). Other studies account for a threshold impact of approximately 5-7\% of GDP, cantered on market composition and accountability, policy requirements and structural structures for some countries with a slightly higher budget deficit, Aero \&Ogundipe (2016). \&

In the case of Pakistan, this report examines the connection between the fiscal deficit and economic development. Its aim is to define a fiscal deficit threshold amount that can act as a macroeconomic policy benchmark. The economy of Pakistan has two noteworthy characteristics. Firstly, it has undergone a historic average growth pace of over $5 \%$, several ups and downs in financial results, with fast development periods accompanied by sharp retardation inevitably (Iqbal, Khan \& Irfan, 2008).

Secondly, several strong development (low growth) periods were recently marked with lower fiscal deficit projections (higher). The overall financial deficit in 2002-2007 was 3.5\%, and a GDP growth rate of 3.5\% was averaged. However, during 2008-2015, the real fiscal deficit was $6.3 \%$, with GDP growth averaging 3.3\%. Taking into account greater leverage over expenditures during the last recovery period, the gross budget deficit has dropped significantly from 8.2 per cent of GDP in the fiscal year 2013 to 4.6 per cent of GDP in the financial years 2016. Development records in the world tend to indicate that in periods of moderate fiscal deficit the economy tends to perform well, while economic development has correlated to increased fiscal deficits. This indicates that there could be a fiscal deficit threshold amount that can be targeted by policymakers to foster economic development while preserving macroeconomic stability.

A big aspect of this analysis is that the seamless transformation is used auto regressive model (STAR) to analyse the potential existence of a model fiscal deficit threshold level. A continuous transformation is used by the model function to catch the non-linear correlation between the variables. This is unlike prior experiments using just a square word to estimate the degree of the threshold, Qasim, Kemal \& Siddique,(2010) or the threshold model established to measure threshold inflation by Khan and Senhadji (2001) Onwioduoki t\& Bassey, 2014). 
The budgetary imbalance is commonly referred to as the income-expenditure divide. In fact, there are three think tanks on the budget gap ramifications. It is neoclassical first, Keynesian second and Ricardian third. Increased budget deficit according to the Neoclassical approach leads to higher interest rates because of higher loan able fund demand which discourages private investment, leads to higher inflation, and slows economy growth rates through the crowding of capital. The Keynesian strategy has demonstrated that the budget gap contributes to higher domestic production, higher gross consumption, more spending and investments at the rate of interest. The point is that the budget gap contributes to higher domestic demand that stimulates further spending by private investors, which yields crowdin1 effects. Finally, the key point of the Ricardian is that the shortfall only delays existing taxation into potential (Bernheim, 1989). This strategy does not impact aggregate demand in the market, as this indicates. The idea is that governments fund the expense either by taxing taxes on taxpayers or may raise capital. And this credit would eventually be compensated by the potential rise in tax. In reality, then, there would be an option between tax and tax now. The people already have enough funds to use by funding the government by investing to avoid tax payers, but they know that more tax will have to be charged in the future to continue to save the money. This extra tax saving would minimize increased investment, which holds overall demand the same (Padda, 2014).

Planning in any sector and organization is an essential element in progress. In any success or loss economic preparation plays a crucial function in the enterprise. Even if the strategy is one entity or for a whole nation, effective preparation succeeds. This strategy is called expenditure when it comes to financing. Budgets are incredibly helpful to help establish and build the country's policies. When its Government expenditure tops its receipts, the discretionary gap is known. Economic patterns impact or control development many strategies to minimize budget deficits. Economic development is calculated as an extra amount of GDP.

Economic development improves the country's commodity output and its wealth. Living Quality as the economy becomes stronger, a country's people would be higher. The policies of the country are relevant the position of its manufacture. Traditionalists contend that a nation is harmful to growing its budget gap. The Ricardian claim that the debt is not detrimental to the economy. One of the biggest economic problems being a massive and large fiscal gap.

Pakistan and this fiscal deficit also trigger several problems, such as low growth, high inflation and lower investment. Pakistan has been faced with currentaccount deficits since the last fifty years. Financial loans that caused international indefensible debt. Balanced budgets for long-term sustainable development it's important. When a nation has a budget deficit crisis, it indicates that the public savings amount is adverse that's detrimental to economic development. Factors such as labour, money, natural are defined by economic development. Some economists claim that budget deficits allow the economy to expand as a consequence of 
productive costs, such as schooling, housing, etc., although other economists say that development is damaging to the debt. They are in favour of neoclassical economies.

\section{Literature Review}

The impact of tax debt on sustainable development is empirical literature. Deficit. Deficit. The deficit. Fischer's (1993) cross-sectional evidence indicates a detrimental association between budget deficit and economic development endorsed by Easter and Rebelo (1993). A variety of reports have shown a negative budget deficit and development in Pakistan. Fatima, Ahmed and Rehman, 2011; Iqbal \& Zahid, 1998; Shabbir\& Mahmood, 1992 others did not feel this relation to be significant (Ahmad, 2013; Nayab, 2015).

Gupta et al. (2005), on the other side, has a strong correlation. Medium and long-term fiscal and economic inequalities. They expect to have a positive effect on effective and non-productive spending. Osborn and Haque (2007) consider public expenditures and clarify that if budget deficit is accountable for effective spending, the conflicting findings prompted researchers to investigate the possibility, both the negative and the positive relationship between the two, of a non-linear fiscal deficiteconomic growth association. The idea is that the fiscal divide should be below the amount that might contribute to economic growth and impede progress.

The threshold impact is based on the claim of Fay and Porter (2006) relative importance of national factors, such as the interaction of weakness dealer. This entail adjustments in the burden of debt, revenue and expenditure make-up, macroeconomic indicators, the volume of national debt and the estimated effects of the budget phase's particular policy and procedural aspects. They further claim that the law requires government leaders to follow such restrictions by setting a budget deficit standard.

Adam and Bevan (2005), in a panel of 45 developing countries, use the Bootstrap method to calculate the deficit threshold.

Find proof of a threshold impact for developed countries of fiscal deficits of about 1.5\% GDP. For developing countries. Yet other analysis suggests higher still.

The threshold stages for emerging economies. For example, onwioduokit (2012) points out a degree of budget deficit for 5 percent of GDP western African Monetary Zone nations. Onwioduokit is the same (2013), with Sierra Leone's expected GDP threshold at 7\%, and says that the difference between the budgets is adversely affected by development.

The deficit threshold for Gambia is estimated by Onwioduokit and Bassey (2014) at 6\% of GDP. Aero and Ogundipe (2016) looked back at Nigeria's development in terms of fiscal deficit consequences and set a 5 percent GDP standard for a regressive threshold for vehicles. 
In general, the theoretical literature determines the fiscal threshold and, depending upon country specific characteristics like business structure, transparency and policy, the deficit is $1.5 \%$ to $7 \%$ of GDP. Some research has investigated the capability to non-linearly relate Pakistan's fiscal deficit to economic development. Ali Ahmad (2010) relates to a threshold of positive development that has a negative effect on the financial divide. The latest results in Qasim et al. (in press) suggest that the budget deficit cap for Pakistan is equal to $0.74 \%$ of GDP. Sees experiments, though, ignore structural theoretical basis and use simplified nonlinear equations to find a smooth transition of variables. However, the current study uses a rigorous theoretical approach for approximating the fiscal deficit threshold using the STAR scale - focused on data from time series. Multi research funding for this technique is considerable. Show that the STAR model is a major nonlinear form of estimating the threshold rates (see van Dijk, Teräsvirta\&Franses, 2002 amongst other items; Mercedes, 1985 Iqbal \& Anwar, Nawaz, (2014).

The effect of the Budget Deficit on the external sector in Pakistan was examined and Chaudary and Shabbir (2005) considered fiscal and monetary variables necessary to maintain financial stability in that sector. The OLS model was used. They analysed budget deficits in terms of the degree and balance of payments and money supply, price and production. They said it is important to prevent shortrun devaluations and currency needs to be stabilized to monitor the changes in the sum of liquidity, prices and reserves. In order to ensure equilibrium, all fiscal and monetary policies must be consistent, since monetary policy initiatives are based on fiscal policy.

Rehman (2010) investigated the relationship between deficit and development, noting that there is a relationship between deficiency and growth although efficient expenditure is positive for growth. Bos, Haque and Osborn, 2003, reviewed a partnership between 30 developed countries with regard to deficits and development and found that the expenditure of productivity such as health, education and capital has supported economic growth. Mohanty (1997) analysed the link between fiscal deficit and development for the longer and short term. He acknowledged that a negative long-term correlation between deficit and development helps to reduce the growth of large fiscal deficits. Alfredo Schclarek (2004) analysed debt-to-crowd relationships in developed and industrial economies and observed that growth rates are strong for developing countries where international debt is smaller. And between debt and economic development, there is no connection. The quarterly data from the oil production nation in the United Arab Emirates of 1973-1995 were obtained by Ghali and Al-Shamsi (1997). They also established an endogenous model of development. They discovered that increased investments improve a country's prosperity. Investment is also linked favourably to economic development. They have been studying the effect of monetary policy on economic development with the co-integration and the causality test by Granger. In his research, Shojai (1999) found that deficit spending often triggers internal sector failure and, in the developed world, a heavy price rise. The fiscal gap further 
destroys currency and interest rates, undermining the economy's foreign competitiveness. In his analysis, he used the normal least square procedure.

In order to figure out the short-term and long-term impact on deficit, debt and development of Pakistan's economy, Ilyas and Siddiqui (2011) analysed the effect of income disparity, debt pressure, and economic growth. They find that the income gap is limited and expanded in relation to budget deficit and inflation, whereas the income gap has little impact on the debt load. Their remarks have claimed that the key method for maintaining and running an economy is connectivity and mobilisation. Revenues are really relevant since countries set income goals for their country while producing budgets. Most experiments have analysed the impact of the macroeconomic factors on budget deficits, but it has been found over time that the effects of budget deficit fluctuations have not been achieved other than economic variables. In terms of the economic variables' impact, several analyses were country-specific, e.g. Lozano (2008) examined the long-term relationship in Colombia between budget deficit, money supply and inflation.

The study shows that money and expenditure gaps are available on a casual basis. The economic variables influencing the South Africa budget deficit, which were reported by Murwirapachena et al. (2013), indicate that with the exception of external debt, all other variables had a positive influence on the fiscal deficit, including high unemployment, slow economic growth, high government expenses and low foreign reserves. Zonuzi et al. (2011) also specified a critical positive relationship between Iranian budget deficits and inflation, following Pesaran et al. (2001) in the years 1971 to 2006 Bayar \&Smeetsanalysed empirically the economic, institutional, and political influences influencing budget deficits in the $15 \mathrm{EU}$ countries (2009). Different methods to analytics i.e. in the panel Right Standard Errors (PCSE) and Fixed Effect Methods, the effects of the unemployment rate, the GDP growth rate and debt service costs, policy and institute variables on budget deficits have been included. The results indicate that unemployment and debt maintenance costs and a fiscal gap are associated favourably.

The influence of the Maastricht Treaty on the budget deficit suggests a deficit reduction for EU countries, but the fragmentation of the government and the index of ideology are negligible for the budget deficit. The economic theory may only explain the budget deficit, according to Alesina\&Perotti (1996). The main determining factors in this field, illustrating the position of the electoral mechanism, legislative division, party composition, and political polarization, are structural and political variables. Empirical analyses of the budget deficit channels in 125 countries were performed by Agnello\&Sousa (2009), who utilized panel-based data techniques. The findings demonstrate that the fiscal gap is rising as a consequence of political uncertainty. In addition, observational results show a major impact of budget deficit fluctuations on the scale of the economy and the political regime. Moreover, increased growth and transparency impact the budget gap dramatically. Javid et al. (2011), contrasts ASEAN countries and South Asian countries by investigating the impact of demographic, policy and structural variables on budget deficit for four South Asians and five ASEAN countries utilizing GMM techniques 
for the duration 1984-2010. Political uncertainty, corruption, law \& order and wars often contribute to a significant budget gap in the context of institutional variables. Yet, when contrasted with chosen South Asian countries, the findings show that increases in the budget deficit are smaller in ASEAN countries. The impact of policy corruption on budget deficits has been studied by Žurauskas (2015) from 1996-2013 in 31 OECD countries. The findings show that higher corruption is related to higher fiscal expenditure utilizing the weighted less square model and control variables; GDP Development and Old Age Dependence Ratio. The GDP growth rate is concurrently strongly related to the budget deficit. Very little research is possible in the case of Pakistan. It stresses primarily the consequences on the budget gap of economic factors and outcomes are different. In Pakistan for the duration from 1976 to 2009, Anwar and Ahmad (2012) described political variables that affect the budget deficit. The autoregressive distributed lag (ARDL) paradigm is used to define longterm co-integration relationships and the error correction (ECM) model. However, democracy helped minimize the budget deficit, even though the influence in the case of Pakistan is poorer during the provided time, in the case of the government scale has a positive and important effect on the Budgets. The literary analysis indicates that there is no misunderstanding of the position of institutional factors in assessing the budget deficit. However, no work is possible to assess the budget deficit effect of policy variables in Pakistan. It is therefore important to research the role of institutional variables in deciding Pakistan's budget deficit.

For the period 1990 to 2006, Huynh (2007) undertook its analysis during the compilation of data from Asian developing countries. He concluded that the budget deficit has a negative effect on the country's GDP rise, while evaluating Vietnam's current trends. In comparison, the crowding-out surfaces were concluded with increasing the budget deficit pressure. The budget deficit and the long-term nominal interest rate have solid, substantial and constructive relationships in a report on the United States of America from 1971 to 1984 (Cebula, 1988). Saleh (2003) observed that the budget deficits have varied effects on various economic variables on the basis of previous studies performed by economists on the impacts of the budget deficit on different economic variables. The relationship between fiscal deficit and economic development is essential to decide. For sustainable economic development, a balanced budget is critical. The rise and fiscal gaps as government expense is higher than their production raise in overtime production. Some economists claim that the connection between budget deficit and economic development is favourable as spending comes from the expenses of output, including schooling, health and so on. This study shows an independent variable in budget difference, as well as a contingent variable in economic growth. The analytical views of the fiscal deficit involve Keynesian and Neoclassical schools and the theory of rational anticipation affect economic development. 


\section{Theoretical Model}

The neoclassical solution is to reduce fiscal deficits economic prosperity through pressurizing and thereby crowding interest rates out corporate investment private investment (Saleh \&Harvie, 2005). School of Keynesian it is expected to contribute to stronger development by a rise in government expenditure by raising overall demand (Nawaz \& Khawaja, 2016). Taxation the deficit causes domestic output to rise, allowing private production more positive investors regarding the economy's prospects, which results more spending - alluded to as "crowding in" by Bernheim (1989). In this sense, an expansionary fiscal policy enhances the general fiscal policy the debt and portion of private investments drains the government deficit financing developed. Growing the budget gap aggregate demand, encouraging jobs and production in exchange.

But the fiscal shortfall has been rationally predicted by the college no economic activity stimulus role: logical agents change their expenditure since they intend to raise taxes to fund this deficit (Saleh and Harvie, 2005) (Barro, 1989). In order to conceptualize the economic growth position of the fiscal deficit, we using the Mankiw, Romer and Weil development model (1992) as an explicative variable, the federal deficit.

\section{Data}

The methodological research is focused on evidence from the time series 1972-2014. 1972. Per capita GDP, physical capital and steady rates the Penn World Table 9.0 is used to take human resources (published by the center for Production and Growth in Groningen. Real per capita GDP is centered on the demographic division of the actual GDP. The stock is money centered on and is based on prior investments accumulation and depreciation. The permanent inventory method was calculated (see Feenstra, Inklaar\& King's Throne, 2015). Human capital is calculated according to the index of human capital, this is focused on school years and college return. The 2016/17 Pakistan Economic Survey and 2015 State Bank of Pakistan Statistics Manual have been used to extract the budget deficit estimates. Difference between spending and profits is measured as a budget shortfall separated by GDP. Both variables are subject to log transformations.

\section{Material and Methods}

In the Dickey-Fuller Improved Assessment (ADF) the normative properties of variable time scales have been tested (Dickey \& Fuller, 1979). In this study the testing approach for automated regression distributed latency is used through cointegration suggested by ARDL and Pesaran. Smith has measured the long-term association of the factors (2001).

We use the Teräsvirta STAR model to measure the fiscal deficit threshold in Pakistan (1998). The model improves the self-development model which is also used to predict non-linear relations in time series outcomes since it allows changes 
simpler between different regimes easier. In order to detect device shifts, instead of the indication feature used for self-regressive thresholds, STAR model uses logistic and exponential functions, Nawaz,VanDijk et al. (2002) also proven to be sufficient for the phase of regime transition to the STAR model for the analysis of nonlinear variables. The following measures are part of the modelling cycle:

- Specify the required linear auto-regressive p order model. Criteria for model collection. This is the foundation for a model that is not linear.

- Checked the zero-linearity hypothesis against the STAR alternative not linearity. Not linearity. If the evaluation does not oppose linearity, pick the right one variable change between potential variables. The Shapes a logistic or exponential transitional feature might be available.

- Estimate the parameters using the chosen STAR model the phase proceeding.

- Assess the adequacy of the model with different diagnostic tests including. Correlation between sequences, inconsistent variation and normality. Change if needed a fitting STAR model to be obtained.

- For descriptive and statistical purposes utilizing the final one.

This study analyses the fiscal deficit and economic relationship between Pakistan to see whether there is a fiscal deficit threshold which could serve as a guideline for fostering development through fiscal expansion. For the duration 19722014 , the analyses apply the STAR model to the series of results. We notice a fiscal deficit threshold of $5.57 \%$ of GDP in Pakistan. In the past, the fiscal deficit has had a detrimental influence on Pakistan's economic development, which has stayed generally above the threshold. This illustrates that macroeconomic policymakers ought to maintain the budget deficit within the threshold to prevent undesirable development effects. It may be tempting to claim that a budget gap is below the amount this threshold is ideal because fiscal stimulus will boost economic development and foster inflation under reasonable limits. However, only when public funding depends on long-term expenditures that produce sufficient returns on housing, schooling, health and other growth programs can the gains of a program be accomplished. Such government investments may also increase private capital's marginal efficiency. This suggests that investing in public resources will "crowd in" private spending to supplement private capital, reinforcing the economic development mechanism.

Finally, the threshold stage of the fiscal must be alert the deficit is not an ideal deficit degree that ensures the requirements for inter temporal solvency. It clearly reveals that politicians could use fiscal deficits as a benchmark, which could probably hamper economic development. Moreover, the threshold level could be sensitive to deficit funding composition, i.e. as a consequence of adjustments in deficit funding strategies, the threshold level of the fiscal deficit may increase or fall. Future studies can explore how the fiscal deficit threshold relies on numerous funding choices, including government borrowing. 


\section{Results and Discussions}

GDP and other independent variables such as labour, investment and fiscal deficit are contingent variables. The overall market value of all the final products produced in a year in a given year is the gross domestic product. It is equivalent to overall consumption, with the addition of government spending, expenditure, exports and imports. GDP covers certain products that are manufactured within a country's geographical boundaries. GDP can be considered to be the economy's scale. It is possible to describe gross domestic product in three different ways, giving the same results. First, the cost strategy is that the total expenditure of all final goods and services for a specific object is equal to the total expenditure. Second is the path to revenue that is equal to the overall revenue provided by development. Thirdly, in any phase of output, it is proportional to the total value added. For a nation as a whole, fiscal strategy is called a budget. The budget is a very valuable tool for helping

Countries in developmental policy making. It indicates a country's earnings and spending. For a country's sustained economic growth and a balanced budget are very significant. The budget can be a shortfall or a surplus. The fiscal deficit is simply referred to as the shortfall of revenue from public sector spending. Often, the fiscal deficit is when it is related to federal budget expenditures, called national debt.

\section{Conclusion}

This report concludes that the budget gap has a positive and important effect on economic development. The causation test of VAR granger reveals GDP is the root of savings and deficit spending. GDP in this analysis is an addictive variable. Fiscal gap is unsustainable when GDP rises at 7 percent today, regardless of budget deficit. This analysis also uses a co-integration test. The integration of the 0.05-degree equation is shown by the trace statistics. No co-integration implies Max Eigen value test. In contrast with Max Eigen statistics, trace statistics are favoured. The statistics is larger than 2, which is important but the symbol is technically inaccurate.

This research explores the effect on Pakistan's budget deficit of macroeconomic and structural variables. It employs co-integration approaches to observe the long-term association between institutional factors and the budget deficit. The thesis explores empirically the results of economic and structural factors which may influence Pakistan's budget deficit. The findings suggest that growth is favourably related to budget deficits. But actual per capita production has no effect. Neither can actual per capita production have some major impact on budget deficits when institutional factors such as bribing, law and order, democratic security and military politics are integrated in the model. This stipulates that demographic conditions alone cannot decide the economic factors that impact an economy's budget deficit. The main determinants of the problem Alesina\&Perotti are political and structural variables (1996). The findings suggest that higher corruption, low administrative efficiency and the state of law and order will raise the deficit. However, the fiscal balance may be influenced favourably by political stability. The 
findings of this analysis have contributed to the key consequences for the government of lowering budget deficits by enhancing the efficiency of agencies and concentrating on the law and order as well as on economic stability.

The relationship between fiscal deficit and economic growth in Pakistan to decide whether the fiscal deficit threshold exists, which could serve as a policy test to promote fiscal expansion growth. For the duration 1972 to 2014, the analyses apply the STAR model to series results. We notice a fiscal deficit threshold of $5.57 \%$ of GDP in Pakistan. In Pakistan, the fiscal deficit has traditionally had a detrimental effect on economic development, usually beyond the threshold mark. This indicates that the financial deficit must be kept below the threshold amount by macroeconomic policy in order to prevent undesirable development effects.

It may be tempting to claim that a budget shortfall is smaller than the threshold is ideal since fiscal stimulus will boost economic investment and stimulate inflation under reasonable limits. However, only if public funding relies on longterm expenditure to produce sufficient returns on housing, schooling, health and other improvements can such a program be effective. Such public spending may also boost private capital's marginal efficiency. This suggests that public money, by complementing private capital, will then "crowd" private expenditure into public capital, enhancing the economic development mechanism.

Finally, the threshold amount of tax must be warned the shortfall is not an ideal deficit degree preserving the requirements of inter-temporal solvency. It merely suggests a deficit amount that lawmakers could use as a benchmark, which could theoretically hamper fiscal growth. Moreover, the threshold amount may depend upon the deficit financing composition, i.e. the fiscal deficit threshold level may increase or decrease as a consequence of adjustments in deficit finance procedures.

Various strategies and suggestions to reduce the fiscal shortfall are proposed. There is a fiscal shortfall as government expenditure exceeds revenues typically. This phenomenon thus produces a shortfall. If shortfalls are unsustainable, higher interest rates can contribute to a lack of government confidence. And will default the nation. The government should raise the taxation and slash public budgets to minimize the budget gap. Yet economic output may be weaker.

\section{Recommendations}

Different strategies and suggestions to eliminate the fiscal deficit have been proposed. Generally, a budget deficit exists when fiscal expense is much more than taxes collected. This phenomenon, however, generates a shortfall. If deficits remain unsustainable, higher interest payments will result in a lack of confidence in the budget and in the government. The government should raise taxation and slash government spending in order to minimize the budget deficit. It can, however, cause lower economic growth. 


\section{References}

Adam, C. S., \& Bevan, D. L. (2005). Fiscal deficits and growth in developing countries. Journal of Public Economics, 89(4), 571-597.

Agha, A. I., \& Khan, M. S. (2006). An empirical analysis of fiscal imbalances and inflation in Pakistan. SBP research Bulletin, 2(2), 343-362.

Aghevli, B. B. (1975). The balance of payments and money supply under the gold standard regime: US 1879-1914. The American Economic Review, 65(1), 40-58.

Aghevli, B. B., \& Khan, M. S. (1977). The monetary approach to balance of payments determination: an empirical test. The Monetary Approach to the Balance of Payments, 275-290.

Agnello, L., \& Sousa, R. M. (2009). The determinants of public deficit volatility. Working Paper Series No. 1042.

Ahmad, H., \& Millar, S. M. (2000). Crowding-out and Crowdinging Effects of the Components of Government Expenditure.

Ahmad, N. (2013). The role of budget deficit in the economic growth of Pakistan. Global Journal of Management and Business Research, 13(5), 1-5.

Akinbobola, 1. O. (2011). Budget Deficit and Inflation in Nigeria: A Causal Relationship. Journal of EmergingTrends in Economics and Management Sciences.

Alesina, A., \&Perotti, R. (1995). The political economy of budget deficits. Staff Papers, 42(1), 1-31.

Alesina, A., \&Perotti, R. (1996). Income distribution, political instability, and investment. European economic review, 40(6), 1203-1228.

Ali, S., \& Ahmad, N. (2010). The effects of fiscal policy on economic growth: Empirical evidences based on time series data from Pakistan. Pakistan Development Review, 49(4), 497-512.

Andreas G. Georgantopoulos, A. D. (2011). The Macroeconomic Effects of Budget Deficits in Greece: A VARVECM Approach. International Research Journal of Finance and Economics.

Anwar, M., \& Ahmad, M. (2012). Political determinants of budget deficit in Pakistan: An empirical investigation (No. 135). HWWI Research Paper.Bayar, A. H., \&Smeets, B. (2009). Economic, political and institutional determinants of budget deficits in the European Union. CESifo Working Paper No. 2611.

Barro, R. J. (1989). The Ricardian approach to budget deficits. Journal of Economic Perspectives, 3(2), 37-54. 
Bernheim, B. D. (1989). A neoclassical perspective on budget deficits. Journal of Economic Perspectives, 3(2), 55-72.

Bernheim, B. D. (1989).A neoclassical perspective on budget deficits. The Journal of Economic Perspectives, 3(2), 55-72.

Bose, N., Haque, M. E., \& Osborn, D. R. (2007). Public expenditure and economic growth: A disaggregated analysis for developing countries. The Manchester School, 75(5), 533556.

Chaudhary, M. Aslam and Kiyoshi Abe (1999).Pakistan economy: Current situation and future prospects. Chiba University Economic Journal, 14(1), 49-85

Christopher S. Adam, D. L. (2004). Fiscal deficits and growth in developing countries. Journal of PublicEconomics 89 (2005) 571- 597.

Dickey, D. A., \& Fuller, W. A. (1979). Distribution of the estimators for autoregressive time series with a unit root. Journal of the American Statistical Association, 74(366), $427-431$.

Drazen, A. B. (2008). How Do Budget Deficits and Economic Growth Affect Reelection Prospects? Evidencefrom a Large Panel of Countries.

Easterly, W., \&Rebelo, S. (1993). Fiscal policy and economic growth: An empirical investigation. Journal of Monetary Economics, 32(3), 417-458.

Fatima, G., Ahmed, A. M., \& Rehman, W. (2011). Fiscal deficit and economic growth: An analysis of Pakistan's economy. International Journal of Trade, Economics and Finance, 2(6), 501-504.

Fatima, G., Ahmed, M., \& Rehman, W. (2012). Consequential effects of budget deficit on economic growth of Pakistan. International Journal of Business and Social Science, 3(7), 203-208.

Goher Fatima, A. M. (2011). Fiscal Deficit and Economic Growth: An Analysis of Pakistan's Economy.

Goher Fatima, M. A. (2012). Consequential Effects of Budget Deficit on Economic Growth of Pakistan.

Keho, Y. (2010). Budget Deficits and Economic Growth: Causality Evidence and Policy Implications forWAEMU Countries. European Journal of Economics, Finance and Administrative Sciences.

Khattak, A. Q.-u.-R. (2008). An Analysis of Short-Term Effects of Budget Deficits on MacroeconomicVariables: Evidence from Pakstan (1960-2005). 
Maji1, A., Ali S. Yusufu Bagaji2, *., Etila3, M. S., \& Sule4, J. G. (2012). An Investigation of Causal Relationship Between Fiscal Deficits, Economic Growth and Money Supply in Nigeria (1970-2009).

Mohanty1, R. K. (1997). Fiscal Deficit-Economic Growth Nexus in India: A Cointegration analysis.

Mushtaq, A. Muzaffar, M. Ali, A . (2017). Political Instability and the Budget Deficit in Economy: A Case of Pakistan. Pakistan Social Sciences Review ,1(1),1-20, doi:10.35484/pssr.2017(1-I)01

Muzafar Shah Habibullah, C.-K. C. (2011). Budget Deficits and Inflation in Thirteen Asian DevelopingCountries. international journal of business and social science, 1-10. 